\title{
KEANEKARAGAMAN JENIS DAN KELIMPAHAN POPULASI SERANGGA AIR SEBAGAI INDIKATOR BIOLOGIS CEMARAN AIR PADA DAS DI LANGOWAN
}

\section{SPECIES DIVERSITY AND POPULATION ABUDANCE OF AQUATIC INSECT AS BIOLOGICAL INDICATORS OF WATER CONTAMINATION IN THE WATERSHED LANGOWAN}

\author{
R.T.D. Maramis dan Henny V.G. Makal*) \\ "Dosen Fakultas Pertanian Unsrat Manado
}

\begin{abstract}
Aquatic insects are one of the organisms that are used in determining water contamination. Aquatic insects are sensitive to the presence of waste dumped in the river and some are resistant to such waste. One of insect resistant waste is Chironomidae. The research objective was to determine aquatic insect species, population abundance by calculating indices diversity and biotic index. Aquatic insects in the lake watershed Tondano were collected by kicks and Hand Picking.

Result showed that seven orders, theerteen families and sixteen species had been identified. The number of highest aquatic insect was found in Noogan which were 13 species, whereas in karondoran were 9 species. Aquatic insects were identified including, Heptagenia sp, sp Baetis sp, Caenis sp., Hydropsyhe, sp and Chrironomidae. The highest aquatic insect populations were collected in Karondoran followed by Winebetan and Noogan. The highest diversity index of aquatic insects was found in Winebetan whereas the lowest was in Karondoran. The lowest value of the biotic index was identified in the region Noogan suggested that water in Noogan area was clean water compared to Winebetan and Karondoran.
\end{abstract}

Key word: Types and aquatic insect populations

\section{ABSTRAK}

Serangga akuatik merupakan salah satu organisme yang digunakan dalam menentukan cemaran air. Serangga air ada yang peka dengan adanya limbah yang dibuang pada aliran sungai dan ada pula yang tahan terhadap limbah tersebut. Salah satu serangga yang tahan terhadap limbah adalah Chironomidae. Tujuan penelitian adalah mengetahui jenis serangga akuatik, populasinya dan menghitung indeks keanekaragman serta bitoik indeks. Serangga akuatik pada daerah aliran sungai danau Tondano diperoleh melalui cara tendangan dan Hand Picking.

Dari hasil penelitian telah ditemukan 7 ordo, 13 famili dan 16 species. Jumlah serangga akuatik tertinggi ditemukan di Noogan 13 jenis, dan tergolong rendah diperoleh di karondoran 9 jenis. Jenis serangga akuatik yang ditemukan diantaranya, Heptagenia sp, Baetis sp, Caenis sp., Hydropsyhe, dan Chrironomidae. Populasi serangga akuatik yang tertinggi untuk ketiga wilayah terdapat pada Karondoran 38 individu, kemudian diikuti Winebetan 25,5 individu dan Noogan 25,5 individu. Nilai indeks keanekaragaman serangga akuatik yang tertinggi ditemukan Winebetan $\mathrm{H}^{\mathrm{i}}=2,37$, dan terendah Karondoran $\mathrm{H}^{\prime}=2,09$. Sebaliknya nilai biotik indeks terendah ditemukan di wilayah Noogan $\mathrm{Bl}=2,09$, kemudian diikuti $\mathrm{Bl}=2,14$ dan tertinggi $\mathrm{BI}=2,21$. Hal ini menunjukkan bahwa pada wilayah Noogan tergolong air bersih dibandingkan dengan Winebetan dan Karondoran.

Kata kunci : Jenis dan populasi serangga akuatik 


\section{PENDAHULUAN}

Melihat begitu penting serangga air untuk menentukan akan kualitas lingkungan, tetapi penelitian serangga air di daerah aliran sungai di Indonesia maupun Sulawesi Utara masih sangat kurang, sehingga data dan informasi tentang serangga air masih sangat terbatas. Penelitian serangga air akan diarahkan pada wilayah Langowan karena merupakan salah satu daerah sentra produksi tanaman pangan dan hortikultura di Minahasa. Di wilayah ini petani-petani masih sangat tergantung insektisida untuk mengendalikan serangga hama.

Tingkat cemaran dapat diketahui dengan mungkur pH, DO dan BOD yang dilakukan dengan metode fisik dan kimia. Cara ini relatif sederhana, tetapi karena tidak dilakukan secara kontinyu hasilnya hanya memberikan data sesaat, pada hal terjadinya pencemaran berlangsung secara kontinyu. Uji hayati yang menggunakan serangga indikator lebih dapat memberikan data cemaran daripada metode fisik dan kimia. Sebab serangga air mengalami cemaran secara terus menurus sepanjang masa hidupnya. (Sudaryanti $d k k$., 2000). Hal ini dapat ditunjukkan dengan adanya perubahan jenis serangga air sebagai indikator cemaran air di danau Richmond (Inggris). Dari pengamatan tiga puluhan tahun ditemukan 17 species Odonata, pada tahun 40an hanya ditemukan 12 species dan pada tahun 60an hanya tertinggal 9 species. Hal ini dipengaruhi akibat adanya pembangunan fisik dan baham kimia (Samways, 1995).

Sembel dkk. (1993) dalam penelitiannya melaporkan bahwa penggunaan insektisida sintetik telah mempengaruhi jenis dan populasi serangga air di daerah persawahan Kecamatan Langowan Kabupaten Minahasa. Aplikasi insektisida Mipicin dan Diazinon jumlah jenis serangga air 20 Jenis, Furadan 18 jenis, dan kontrol 24 jenis. Populasi serangga air yang tertinggi selama 6 kali pengambilan contoh ditemukan pada Chironomidae, dimana pada perlakuan insektisida Diazionon 288 individu per 5 gayung, Mipcin 245 individu per 5 gayung, Furadan 293 individu 5 gayung, dan kontrol 245 individu.
Survei yang dilakukan oleh Rimbing dan Rondonuwu (2001) pada daerah aliran sungai Molmoi sekitar pertambangan emas MSM di Likupang telah ditemukan 6 ordo seranga air, terdiri dari 20 famili, dan 27 jenis diantaranya Baetis sp., Hydropsyche sp., dan Blastorus sp. Serangga tersebut merupakan indikator terhadap cemaran air. Jenis serangga air yang ditemukan di wilayah Likupang makin ke hilir jumlah jenisnya makin berkurang hanya 9 jenis, sedang hulu 27 jenis. Sebagaimana yang diuraikan di atas bahwa jenis serangga yang diteliti masih berorientasi pada pemukiman, dan daerah pertanian, sedang kajian serangga air pada hutan belum banyak dikaji. Data jenis serangga air pada kawasan hutan sangat berguna karena biasanya wilayah ini belum tercemar, oleh karena itu data serangga air pada kawasan hutan dapat digunakan sebagai pembanding dengan jenis serangga air pada daerah aliran sungai di pemukiman, pertanian, dan persawahan.

Menurut Lehmkul (1979) bahwa derajat kejernihan atau polusi air dapat dipelajari melalui keadaan serangga yang hidup dalam air. Penetapan air tergolong bersih atau kotor dapat diketahui dengan melalui penghitungan indeks biotik serangga air (Hilsenhoff, 1977). Adanya pencemaran air Sungai Tondano, dimungkinkan karena adanya limbah rumah tangga yang masuk daerah aliran sungai dan petan-petani sawah di wilayah aliran sungai masih sangat tergantung pada insektisida untuk mengendalikan serangga hama (Sembel, dkk., 1991; Sembel, dkk., 2000). Risali et. al. (2000) melaporkan bahwa sistem pertanian di Gunung Halimun tidak menggunakan pestisida dan banyak ditemukan serangga indikator cemaran air, yaitu Ephemeroptera, Trichoptera, dan Plecoptera. Serangga ini sering digunakan sebagai indikator kesehatan lingkungan (Samway, 1995).

Penelitian ini bermaksud untuk mendapatkan informasi terkini mengenai keberadaan ekosistem air tawar di daerah aliran sungai Tondano, mengingat masih tingginya ketergantungan petani terhadap penggunaan pestisida, juga makin pesatnya perkembangan pemukiman penduduk, menyebabkan terjadinya peningkatan produk limbah rumah tangga. 
Kegiatan ini tentunya dapat mempengaruhi kondisi serangga air atau akuatik yang nantinya akan digunakan sebagai indikator cemaran air. Disamping itu pula dengan adanya jenis serangga air dan penetapan kualitas air di daerah aliran sungai akan sangat membantu dalam menentukan strategi penanggulangan pada daerah aliran sungai DAS Tondono di wilayah Langowan.

Tujuan penelitian adalah untuk mengetahui jenis serangga air sebagai indikator cemaran air, populasi dan menghitung indeks keanekeragaman serta bitok indeks.

\section{METODE PENELITIAN}

Kegiatan penelitian telah dilaksanakan di Kecamatan Langowan Kabupaten Minahasa pada daerah aliran sungai Tondano. Penelitian ini berlangsung selama kurang lebih 5 bulan

\section{Metode}

\section{Penetapan Lokasi Penelitian}

Pengambilan contoh serangga air pada masing-masing daerah aliran sungai dimulai pada daerah hulu dan hilir sungai Langowan. Untuk mengungkapkan jenis-jenis serangga air atau akuatik, maka pada daerah aliran sungai akan ditentukan 3 titik tempat pengambilan contoh yakni Noogan, Winebetan, dan Karondoran. Dari setiap titik tempat pengambilan contoh akan ditentukan 2 tempat pengambilan contoh, sehingga dalam percobaan ini 6 tempat pengambilan contoh serangga air. Pengambilan contoh dilakukan sebanyak 2 kali pada daerah aliran sungai dengan interval waktu sebulan sekali.

\section{Pengambilan Contoh Serangga Air di Sungai}

Jarak antara tempat pengambilan contoh dengan tempat yang lainnya adalah $40-50 \mathrm{~m}$. Contoh serangga air diperoleh melalui 2 cara yaitu pengambilan contoh dengan cara tendangan (Kick sampling), dan hand picking. Cara atau teknik pengambilan serangga akuatik adalah sebagai berikut :

\section{Cara Tendangan (Kick samping)}

Contoh serangga air dan debris diambil dengan menggunakan net serangga berbentuk segi tiga. Net serangga diletakkan di dasar sungai dengan posisi melawan arus, kemudian pasir, krikil dan debris yang ada disekitar net dibongkar dengan menggunakan garpu dan tendangan kaki. Setelah dibongkar kemudian ditunggu selama 10 menit dan selanjutnya net tersebut diangkat dari air. Material yang telah masuk ke dalam net dan bahan tersebut terkumpul dituang sedikit demi sedikit ke dalam saringan yang memungkinkan serangga-serangga air melewati saringan dan ditampung dalam wadah yang diletakkan di bawahnya, sementara material yang lain tertinggal dalam saringan.

\section{Hand Picking}

Pengambilan contoh dilakukan dengan mengumpulkan batu-batuan yang secukupnya di dasar sungai yang merupakan habitat dari serangga air. Batu-batuan dimasukkan ke dalam ember kemudian dituangkan air secukupnya untuk membersihkan serangga air yang menempel pada batu-batuan tersebut. Setiap titik dikumpulkan sebanyak 15 buah batu-batuan yang berukuran sedang dan diambil secara acak.

\section{Penetapan Tingkat Cemaran Air}

Penetapan tingkat pencemaran air dihitung dengan analisis indeks biotik (BI) dengan menggunakan formula dari Hilsenhoff (1977) sebagai berikut :

$$
\mathrm{BI}=\frac{\mathrm{ni} \text { ai }}{\mathrm{N}}
$$

Dimana :

ni adalah jumlah specimen pada setiap kelompok takson

ai adalah skor toleransi polusi untuk kelompok taksoni tersebut

$\mathrm{N}$ adalah jumlah serangga dalam sampel.

\section{Indeks Keragaman Serangga Air (H)}

Tingkat pencemaran air diukur pula dengan indeks keanekaragaman. Untuk mengukur indeks keanekaragaman menggunakan suatu indeks yang dikembangkan oleh Shannon dan Wiever melalui persamaan sebagai berikut :

$$
\mathrm{H}=\text { pi loge pi }
$$

Dimana ;

$\mathrm{H}=$ Indeks keanekaragaman.

pi = Proporsi dari spesies I dalam suatu contoh N spesies. 
Penetapan tingkat kemerataan spesies digunakan analisis indeks kemarataan spesies (Manguran, 1987). Formula indeks kemarataan adalah sebagai berikut :

$$
E=H / l n S
$$

\section{HASIL DAN PEMBAHASAN}

\section{Jenis dan Populasi Serangga Air}

Serangga akuatik yang ditemukan pada ekosistem air sungai pada daerah aliran sungai danau Tondano (DAS) di Kecamatan Langowan dari satu wilayah dengan wilayah lainnya sebagai tempat pengambilan contoh adanya jenis, tetapi ada pula serangga akuatik yang jenisnya sama. Serangga akuatik yang ditemukan dalam penelitian terdiri dari 7 ordo, dan 13 famili, dan 16 species. Dari 7 ordo yang ditemukan pada ekosistem daerah aliran danau Tandano yang dominan adalah ordo Ephemeroptera. Ordo Ephemeroptera tidak hanya terbatas pada pada bagian hulu tetapi terdapat pada bagian hilir danau sungai Tondano di Kecamatan Langowan. Jenis serangga akuatik yang ditemukan pada ordo Ephemroptera terdiri dari Heptagenidae, Baetidae, dan Caenidae. Dari ketiga jenis serangan akuatik yang ditemukan pada daerah aliran sungai yang menjadi dominan atau umum ditemukan adalah Heptagenidae, dan Baetidae.

Untuk jenis serangga akuatik dari Odonata ditemukan dua jenis yakni Agrionidae dan Coenaagrionidae. Jenis serangga akuatik Agrionidae tidak ditemukan pada semua lokasi, tetapi hanya ditemukan di hulu sungai Danau Tondano Kecamatan Langowan. Jumlah serangga akuatik tersebut yang ditemukan hanya 1,5 individu. Serangga akuatik Coenaagrionidae ditemukan pada dua lokasi pengambilan contoh yakni Noogan dan Winebetan. Populasi serangga akuatik tersebut untuk masing-masing lokasi yakni Noogan 1 individu dan 3 individu di Winebetan. Demikian pula serangga akuatik Gerridae dari ordo Hemiptera hanya ditemukan di daerah aliran Danau Tondano Kecamatan Langowan, dengan populasi 5,5 individu. Hal ini pula berbeda dengan lokasi pengambilan di hilir sungai di Kecamatan Langowan, hanya ditemukan satu jenis yakni
Lepidoptera, dan tidak ditemukan di kedua wilayah sebagai tempat pengambilan contoh serangga air.

Serangga akuatik pada ordo Diptera hanya ditemukan 2 famili yakni ceratopagidae dan Chironomidae. Kedua jenis serangga akuatik tersebut terdapat pada semua lokasi penelitian, kecuali Chironomidae tidak ditemukan di lokasi pengambilan contoh serangga akuatik di Noogan. Populasi serangga akuatik untuk Chironomidae tertinggi ditemukan pada lokasi pengambilan contoh serangga air di Karondoran 7 individu, sedangkan ceratopagidae tertinggi ditemukan di Noogan 3,5 individu. Serangga akuatik Trichoptera yang ditemukan di lokasi pengambilan contoh adalah Hydropsychidae, Polycentropodidae dan Philopatomidae. Serangga akuatik dari golongan Hydropsychidae dan Polycentropodidae terdapat pada semua lokasi pengambilan contoh, kecuali Philopatomidae hanya ditemukan pada lokasi pengambilan di Noogan. Populasi yang dominan dan kepadatan populasi tertinggi pada ordo Trichoptera adalah Hydropsyhe sp. Kepadatan populasi serangga akuatik tersebut adalah 10,5 individu ditemukan di Karondoran. Data tentang populasi serangga akuatik pada daerah aliran sungai Danau Tondano di Kecamatan Langowan dapat diikuti pada Tabel 1.

Sebagaimana yang tercatum dalam Tabel 1, bahwa kepadatan populasi serangga akuatik tertinggi ditemukan pada daerah aliran sungai tondano bagian hilir dari Kecamatan Langowan yakni Karondoran. Kepadatan populasi serangga akuatik di Karondoran 38,5 individu kemudian diikuti Winebetan 27,5 individu dan paling rendah adalah Noogan 25,5 individu. Ditinjau dari aspek jumlah jenis menunjukkan bahwa kepadatan populasi serangga akuatik tidak berkorelasi dengan jumlah jenis.

Selama pengambilan contoh serangga akuatik terjadi curah hujan yang cukup tinggi dan sangat mempengaruhi terhadap kepadatan populasi dan jumlah jenis serangga akuatik.

Dengan adanya curah hujan telah mempengaruhi terhadap serangga akuatik yang ditemukan pada lokasi pengambilan contoh. 
Tabel 1. Jenis Serangga Air di Kecamatan Langowan

(Table 1. Types of Insects in the District Water Langowan)

\begin{tabular}{|l|l|l|c|c|c|}
\hline \multicolumn{1}{|c|}{ Ordo } & \multicolumn{1}{|c|}{ Family } & \multicolumn{1}{c|}{ Genus } & Noogan & Winebetan & Karondoran \\
\hline Ephemeroptera & Heptagenidae & - & 2,5 & 4 & - \\
\hline & & Heptagenia & 4,5 & 2 & 1,5 \\
\hline & & Rhitrogena & 1,5 & - & - \\
\hline & Baetiidae & - & 1 & 4,0 & 3 \\
\hline & & Baetis & 4 & 2 & 3,5 \\
\hline & Caenidae & Caenis & 1 & 2,5 & 3,5 \\
\hline & Agrionidae & & 1,5 & 0 & 0 \\
\hline Hemiptra & Coenaagrionidae & & 1 & 3 & - \\
\hline Lepidoptera & Gerridae & & 5,5 & - & - \\
\hline Diptera & Pyralidae & & - & - & 1 \\
\hline & Cerapatoginade & & 3,5 & 1,5 & 3 \\
\hline Trichoptera & Chironimidae & & - & 2 & 7 \\
\hline & Hydropsychidae & Hydropsyhe & 2,5 & 3,5 & 10,5 \\
\hline & Polycentropodidae & & 0,5 & 1,5 & 5,5 \\
\hline Coleoptera & Philopatomidae & & 1 & - & - \\
\hline Jumlah & Elmidae & & 1 & 1.5 & 0 \\
\hline
\end{tabular}

Adanya curah hujan mempengaruhi terhadap aliran sungai yang cukup deras, dan serangga akuatik yang terdapat pada habitat air akan terhanjut dan menyebabkan populasi dan jenis serangga akutik pada tempat pengambilan contoh akan menjadi rendah.

\section{Indeks Keanekaragaman Serangga Akuatik}

Data mengenai serangga akuatik yang dilihat dari aspek indeks keanekaragaman dapat diikuti dalam tabel 2.

Dari data tabel 2 menunjukkan bahwa indeks keanekeragaman serangga akutik tertinggi ditemukan dilokasi pengambilan contoh serangga akuatik di Noogan $\mathrm{Hi}^{\mathrm{i}}=2,37$, dan diikuti Winebetan $\mathrm{H}^{\mathrm{i}}=2,26$ dan paling rendah $\mathrm{H}^{\mathrm{i}}=2,07$ terdapat di Karondoran. Data menunjukkan bahwa jumlah jenis serangga akuatik berpengaruh terhadap nilai indeks keanekaragaman. Jumlah jenis serangga akuatik pada daerah aliran sungai di Noogan 13 jenis, menyebabkan indeks keanekaragaman menjadi tinggi pula. Untuk wilayah pengambilan contoh di Karondoran nilai indeks keanekaragaman sangat rendah, hal ini disebabkan jumlah jenis serangga akuatik sangat rendah dan disamping itu pula terdapat jenis serangga akuatik dengan populasi sangat menonjol yakni Hydropsyche sp. dan Chironomidae.

Dalam kegiatan penelitian menunjukkan bahwa indeks keanekaragaman serangga akuatik dari hulu ke hilir berbeda. Data yang diperoleh dari hasil penelitian bahwa semakin ke hilir nilai indeks keanekaragaman menjadi lebih rendah.

Tabel 2. Indeks Keanekaragaman Dan Kemarataan Serangga Akuatik di Kecamatan Langowan (Table 2. Diversity Index And Cloudy Aquatic Insects in Langowan)

\begin{tabular}{|c|c|c|c|}
\hline No & Lokasi & Indeks Keanekaragaman & Indeks Kemarataan \\
\hline 1 & Noogan & 2,37 & 0,90 \\
\hline 2 & Winebetas & 2,29 & 0,96 \\
\hline 3 & Karondoran & 2,07 & 0,94 \\
\hline
\end{tabular}


Tabel 3. Nilai Biotik Indeks di Noogan, Winebetan, dan Karondoran

(Table 3. Biotic index in Noogan, Winebetan, and Karondoran)

\begin{tabular}{ccc}
\hline No & Lokasi & Indeks Keanekaragaman \\
\hline 1 & Noogan & 2,03 \\
2 & Winebetas & 2,14 \\
3 & Karondoran & 2,38 \\
\hline
\end{tabular}

Hal ini menunjukkan bahwa kualitas air pada daerah aliran sungai Danau Tondano untuk Kecamatan Langowan pada bagian hulu (Noogan) cukup bersih dibandingkan dengan pada bagian hilir yakni Karondoran. Meskipun kualitas air pada Noogan cukup baik dibandingkan dengan Winebetan, tetapi belum berarti bahwa air pada aliran sungai tergolong cukup baik untuk organisme lain, hal ini tidak diketahui batas nilai $\mathrm{H}$ yang tergolong air bersih dan air yang tergolong kotor.

Dari hasil analisis tentang indeks kemerataan serangga akuatik pada masing-masing lokasi pengambilan contoh di Kecamatan Langowan berbeda. Nilai indeks kemerataan serangga akuatik untuk wilayah Noogan $E=0,91$, Winebetan $\mathrm{E}=0,96$, dan Karondoran $\mathrm{E}=0,94$.

\section{Indeks Biotik}

Terdapat serangga akuatik yang peka terhadap pencemaran dan ada pula serangga akuatik yang tahan terhadap pencemaran Lemkhul (1977) menetapkan toleransi pencemaran air sungai oleh serangga akuatik, dimana serangga akuatik yang peka terhadap pencemaran air diberi nilai toleransi $O$, sedangkan yang tahan diberi nilai toleransi 5. Dengan adanya pembagian nilai toleransi serangga akuatik, maka dapat diketahui akan kualitas air. Nilai indeks biotik untuk Noogan, Winebetan dan Karondoran dapat diikuti pada tabel 3.

Dari data tabel 3 menunjukkan bahwa tingkat indeks biotik tertinggi ditemukan di Noogan $\mathrm{BI}=2,03$, kemudian diikuti Winebetan $\mathrm{BI}=2,14$, kemudian yang paling rendah ditemukan di Karondoran $\mathrm{Bl}=2,38$. Hal ini pula sesuai pula dengan dengan nilai indeks keanekaragaman serangga akuatik tertinggi terdapat pada Noongan. Daerah Noogan tergolong kualitas air yang terbaik dibandingkan dengan kedua lokasi pengambilan contoh, hal ini didukung dengan nilai indeks bitoik dan indeks keanekaragaman yang tergolong tinggi. Nilai indeks biotik yang terendah ditemukan di Noogan sebagaimana yang dilaporkan oleh Kandowangko dkk. (2000) bahwa nilai indeks biotik yang terendah terdapat Noogan 2,36, dan paling tinggi Panasen dan Tontimomor masing-masing 2,50 dan 2,84. Hasil penelitian untuk wilayah Karondoran ditemukan serangga akuatik yang tahan terhadap pencemaran air seperti Chironomidae dan Hydropsyhe sp. Kedua jenis serangga akuatik memiliki nilai toleransi yang cukup tinggi yakni nilai 4, sedang Noongan terdapat serangga akuatik yang mimiliki nilai toleransi 0 yakni Philopatomidae.

Lokasi pengambilan contoh Winebetan dan Karondoran merupakan daerah pertanian padi sawah, sedangkan Noogan daerah pertanian tanaman padi sawah sangat terbatas luas arealnya. Untuk Winebetan dan Karondoran daerah aliran sungai diduga banyak mengandung insektisida, sehingga telah mempengerahui terhadap serangga air. Sembel dkk. (2000) melaporakan petani sawah di Sulawesi Utara dalam mengendalikan serangga tanaman padi sawah masih sangat tergantung insektisida sintetik. Dengan adanya insektisida sudah tentu serangga air yang peka terhadap insektisida akan mati dan tertinggal serangga yang tahan. Disamping itu pula insektisida secara tidak langsung mempengaruhi terhadap kualitas, dimana menurunkan kadar oksigen yang terlarut pada air.

\section{KESIMPULAN}

Daerah aliran sungai Tondano di Kecamatan Langowan terdapat 17 jenis serangga akuatik, dan jumlah jenis serangga akuatik yang tertinggi ditemukan di Noogan 13 jenis dan Karondoran terendah 9 jenis. Kelimpahan populasi tertinggi ditemukan di Karondoran 38,5, kemudian diikuti Winebetan 27,5 dan Noogan 25,2 individu. 
Perbedaan indeks keanekaragaman serangga akuatik ditentukan oleh jumlah species yang ditemukan pada setiap lokasi pengambilan contoh. Indeks keanekaragaman tertinggi terdapat di Winebetan $\mathrm{H}^{\mathrm{i}}=2,37$, kemudian diikuti Winebetan $\mathrm{H}^{\mathrm{i}}=2,26$, dan paling rendah Karondoran $\mathrm{H}^{\mathrm{i}}=2,09$.

Nilai indeks biotik serangga akuatik semakin hilir nilai menjadi tinggi. Indeks biotik tertinggi ditemukan di Noogan $\mathrm{BI}=2,09$, dan kemudian diikuti Winebetan $\mathrm{BI}=2,14$, dan paling rendah adalah Karondoran $\mathrm{BI}=2,21$.

\section{DAFTAR PUSTAKA}

Hilsenhoff. WR. 1977. Use of Arthropods to evalued water quality of streams Tech. Bul. No. 100. Dept. Nas. Res. Madison. Wisconsin, pp.1-15.

Kandowangko, D. D.T Sembel, dan M. Tulung, 2000. Serangga Indikator Cemaran Air di Daerah aliran Sungai Tondano, Sulawesi utara. Prosiding Simposium Keanekeragaman Arthropoda pada Sistem Produksi Pertanian, Cipayung.

Lehmkuhl D.M. 1979. How To Know Aquatic Insects The Picture Key Nature Series.

Rimbing, J. dan Rondonuwu, 2001. Kajian serangga-serangga Indikator Terhadap Pencemaran air Sungai Di Likupang Kabupaten Minahasa. Fakultas Pertanian UNSRAT
Risali, A., D. Buchori \& H. Triwidodo. 2000. Keanekaragaman Serangga dan Peranannya Daerah Persawahan di Taman Nasional Gunung Halimun, Desa Malasari, Kabupaten Bogor, Jawa Barat. Prosiding Simposium Keanekaragaman Hayati Arthropoda Pada Sistem Produksi Pertanian. Cypayung.

Samways, MJ. 1995. Insect Coservasion Biology. Champman \& Halt.

Sembel, D.T, F. Kaseger, J. Pongoh dan D. Kandowangko. 1991. Pengkajian Terhadap Penggunaan Pestisida Oleh Petani di Kabupaten Minahasa dan Bolaang Mongondow. Jurnal Fakultas Pertanian Unsrat.

, J. Rimbing, M. Ratulangi., M. Meray. 1999. Pemantauan dan Peramalan Organisme Pengganggu Tanaman Pangan dan Sayuran. Eugenia, Fakultas Pertanian Unsrat Manado.

Sudaryanti Sri, M. Soehardjan, dan Wardojo, 2000. Status Potensi Serangga Akuatik dan Pengembangannya Sebagai Indikator Cemaran Air. Prosiding Symposium keanekafragaman hayati Artropoda Pada Sistem produksi Pertanian. Bandung. 
